\title{
Pengaruh Kualitas Pengungkapan Keuangan dan Struktur Kepemilikan Terhadap Asimetri Informasi
}

\author{
Farma Andiansyah ${ }^{1}$ Slamet Haryono $^{2}$ \\ ${ }^{1,2}$ Universitas Islam Negeri Sunan Kalijaga Yogyakarta \\ Email: ${ }^{1}$ Farmaandiansyah24@gmail.com ${ }^{2}$ Slamet.haryono@uin-suka.ac.id

Diterima Direvisi Disetujui \\ 01-01-2021 15-03-2021 18-03-2021
}

\begin{abstract}
Abstrak-Kehadiran asimetri informasi meningkatkan biaya transaksi dan mengurangi likuiditas, serta mengurangi kualitas keputusan investasi yang diambil oleh investor. Sehingga pada giliranya melemahkan fungsi pasar secara keseluruhan. Pengungkapan akuntansi berperan memobilisasi informasi dari pihak manajemen dan investor sehingga dapat mengurangi asimetri informasi. Selain itu, keberadaan konsentrasi kepemilikan investor dapat melakukan pemantauan di internal perusahaan sehingga dapat mengurangi asimetri informasi. Disisi lain, investor institusi mememiliki banyak insentif dalam mengakses informasi perusahaan dengan tujuan perdagangan mereka dikarenakan konflik kepentingan antara investor pihak luar dan pihak direksi. Penelitian ini bertujuan untuk mengetahui pengaruh kualitas pengungkapan dan struktur kepemilkan terhadap asimetri informasi pada perusahaan yang terdaftar di Jakrta Islamic Index (JII) selama periode 2015-2019. Berdasarkan hasil analisis data panel model Fixed Efect Model (FEM), menemukan bahwa kepemilikan institusional berpengaruh positif signifikan terhadap asimetri informasi sedangakan kualitas pengungkapan dan konsentrasi kepemilikan tidak memiliki pengaruh secara statistik terhadap asimetri informasi.
\end{abstract}

Kata Kunci: Kualitas Pengungkapan, Konsentrasi Pemilikan, Kpemilikan Institusional, Asimetri Informasi

\begin{abstract}
The presence of information asymmetry increases transaction costs and reduces liquidity, and reduces the quality of investment decisions taken by investors. So that in turn it weakens the overall function of the market. Accounting disclosure plays a role in mobilizing information from management and investors so as to reduce information asymmetry. In addition, it is hoped that the presence of a concentration of investor ownership can carry out internal monitoring of the company so as to reduce information asymmetry. On the other hand, institutional investors have many incentives to access company information for their trading purposes due to the conflict of interest between outside investors and the board of directors. This study aims to determine the effect of disclosure quality and ownership structure on information asymmetry in companies listed on the Jakrta Islamic Index (JII) during the 2015-2019 period. Based on the results of panel data analysis of the Fixed Effect Model (FEM), it was found that institutional ownership had a significant positive effect on information asymmetry, while the quality of disclosure and ownership concentration did not have a statistical effect on information asymmetry.
\end{abstract}

Keywords: Quality of Disclosure, Ownership Concentration, Institutional Ownership, Information Asymmetry, FEM

\section{PENDAHULUAN}

Kehadiran Asimetri informasi tidak hanya berdampak pada meningkatkan biaya transaksi dan mengurangi likuiditas, tetapi juga mengurangi kualitas keputusan investasi yang diambil oleh investor, sehingga melemahkan fungsi pasar secara keseluruhan (Nel et al., 2018).Informasi akuntansi merupakan salah satu informasi terpenting yang diandalkan investor di pasar saham. Oleh karena itu, pasar keuangan global sangat mementingkan persiapan dan penyebaran informasi secara berkala kepada investor. Setiap cacat dalam informasi ini menyebabkan asimetri informasi yang tersedia bagi investor, yang berkontribusi pada efisiensi rendah dari pasar keuangan dan secara langsung tercermin dalam harga saham (Al-Sakini, 2019).

Asimetri informasi merupakan suatu kondisi dimana salah satu pihak dalam suatu hubungan memiliki informasi yang lebih banyak atau lebih baik dari yang lain (Bergh et al, 2019). Dalam konteks investasi, asimetri informasi terjadi ketika sebagian investor memiliki informasi pribadi terkait dengan nilai perusahaan sementara investor lain kurang mendapatkan informasi atau hanya memiliki akses ke informasi publik (Vergauwe \& Gaeremynck, 2019). Mengingat biaya dan keterampilan yang diperlukan untuk mengumpulkan informasi, tidak semua investor bisa mendapat informasi yang sama, sehingga ada investor yang mendapat informasi dan investor yang kurang informasi. 
Pemisahan antara kepemilikan dan manajemen dalam kepemilikan saham publik perusahaan telah berkontribusi pada konflik kepentingan antara investor dan manajer. Sebagai manajemen memiliki lebih banyak informasi daripada investor tentang perusahaan, dan ini dapat meningkatkan asimetri informasi, baik antara manajemen dan investor, atau antara Investor sendiri (Nel et al., 2018). Adanya peran penting seorang manajer dalam merefleksikan keadaan perusahaan yang berupa laporan keuangan, akan mengakibatkan ketidak seimbangan informasi antara manajer dan stakeholders. Ketidakseimbangan ini terjadi karena manajer memiliki akses informasi yang sangat besar di perusahaan dibandingkan pemangku kepentingan lainya. Hal itu akan menimbulkan masalah perusahaan (Almurni \& Hendrawati, 2019). Seperti temuan Kalash \& Sabsabi (2018) yang menemukan asimetri informasi yang tinggi dapat memicu leverage yang tinggi yang kemudian berdampak pada berkurangnya kinerja perusahaan.

Dalam teori ekonomi, pengungkapan akuntansi merupakan mekanisme yang baik untuk memfasilitasi transmisi informasi yang aman antara manajemen dan investor, yang memainkan peran penting dalam mengurangi asimetri informasi (Vergauwe \& Gaeremynck, 2019). Setidaknya ada dua alasan peran penting dari pengungkapan akuntansi dalam mengurangi asimetri informasi. Pertama, informasi akuntansi memungkinkan mereka yang menyediakan modal perusahaan termasuk pemegang saham dan kreditor untuk mengevaluasi potensi pengembalian peluang investasi atau menilai atau peran ex-ante informasi akuntansi. Kedua, informasi akuntansi memungkinkan mereka yang menyediakan modal perusahaan untuk memantau penggunaan modal yang dikontribusikan kepada perusahaan atau peran penatalayanan atau ex-post informasi akuntansi (Shiri et al., 2016).

Selain kualitas laporan keuangan, penelitian tata kelola perusahaan menunjukkan bahwa struktur kepemilikan dapat mempengaruhi kualitas pelaporan keuangan, dan dengan demikian berperan efektif dalam pengambilan keputusan pasar modal. Dengan kata lain asimetri informasi dapat lebih buruk pada perusahaan dengan struktur kepemilikan yang lebih terkonsentrasi, kepemilikan institusional yang lebih tinggi, dan kualitas pengungkapan yang lebih rendah (Shiri et al., 2016). Hal tersebut karena berdasarkan hipotesis pemantauan aktif, keberadaan investor institusional diantara pemegang saham perusahaan (Konsentrasi kepemilikan) dapat mengurangi asimetri informasi dan pada giliranya mengurangi biaya agensi, terutama karena peran pemantauan perusahaan. Selain itu, berdasarkan hipotesis kepentingan pribadi, investor institusi memeiliki lebih banyak insentif untuk mengakses informasi pribadi tentang perusahaan untuk tujuan perdagangan mereka. Dalam situasi ini, investor ini kurang tertarik untuk memantau aktivitas perusahaan dan lebih tertarik pada pengungkapan oleh perusahaan dan, oleh karena itu, cenderung meningkatkan asimetri informasi dan pada gilirannya meningkatkan masalah keagenan (Shiri et al., 2016).

Penelitian Nel et al (2018) menunjukan bahwa kualitas pengungkapan dengan menggunakan skala penilaian dari IIR dapat mengurangi asimetri informasi para investor. Dengan kata lain, semakin baik kualitas pelaporan yang dibuat perusahaan yang di tampilkan pada website perusahaan semakin mudah para investor mendapatkan informasi yang berkualitas dalam melakukan keputusan investasi. Dukungan serupa ditunjukan oleh penelitian dari Almurni \& Hendrawati (2019) menemukan relevansi nilai, ketepatan waktu, dan konservatisme sebagai proksi dari kualitas laporan keuangan memiliki pengaruh negatif signifikan terhadap asimetri informasi. Al-Sakini (2019) menemukan pengungkpan berkala laporan keuangan dan volume perdangan berpepngaruh negatif terhadap asimetri informasi.

Sementara, Cheynel \& Levine (2019) mengatakan bahwa baik kualitas dan kuantitas pengungkapan publik sukarela dapat memperburuk asimetri informasi dan bukan menguranginya. Hal tersebut beralasan karena ketika informasi memiliki interpretasi yang ambigu, sehingga sinyal yang sama dapat diinterpretasikan secara positif atau negatif tergantung pada faktor terkait lainnya, penggunaannya dalam mosaik informasi memungkinkan pedagang yang terinformasi untuk menghindari perdagangan yang tidak menguntungkan dengan mengorbankan investor yang kurang informasi.

Bukti empiris terkait peran struktur kepemilikan dalam mendorong asimetri informasi telah ditunjukan dalam penelitian Shiri et al (2016) yang menguji struktur kemilikan dengan proksi konsentrasi kepemilikan saham pemilik utama dan persentase kepemilikan saham yang dimiliki oleh institusional dalam perananya memperparah asimetri informasi. Hasil temuanya menunjukan bahwa kedua proksi yaitu konsentrasi kepemilikan saham utama dan persentasi kepemilikan saham institusional berpengaruh positif terhadap asimetri informasi danpada giliranya meningkatkan masalah keagenan.

Studi empiris sampai saat ini yang telah meneliti pengaruh pengungkapan pada asimetri informasi menghasilkan hasil yang beragam. Hal tersebut dikarenakan adanya proxy yang digunakan berbeda dalam pengungkapan dan asimetri informasi, selain itu metodologi penelitian yang berbeda seperti sampel yang dipilih, dan karakteristik negara tempat data diperoleh misalnya negara berkembang atau maju. Indonesia sebagai negara berkembang dengan populasi Muslim terbesar di dunia dan termasuk negara dengan ekonomi Islam terkuat di dunia menjadi daya tarik bagi peneliti untuk melakukan penelitian selanjutnya pada bursa saham syariah di Indonesia.Penelitian ini bertujuan untuk mengetahui 
pengaruh kualitas pengungkapan dan struktur kepemilikan terhadap asimetri informasi pada perusahaan yang terdaftar di Jakarta Islamic Index (JII).

Kajian pustaka dalam penelitian ini adalah:

\section{Asimetri Informasi}

Nel et al (2018) menggambarkan konsep asimetri informasi sebagai situasi di mana beberapa investor memiliki akses ke informasi pribadi atau investor yang diinformasikan, sementara yang lain hanya memiliki informasi yang tersedia untuk umum atau investor yang tidak mendapat informasi. Pemisahan kepemilikan (investor) dan kontrol (manajemen), ditambah dengan insentif yang saling bertentangan antara investor dan manajer, selanjutnya dapat mengakibatkan manajemen memiliki informasi yang lebih unggul tentang perusahaan, relatif terhadap investor. Oleh karena itu, asimetri informasi dapat terjadi, baik antara manajemen perusahaan dan investornya, atau antara investor itu sendiri.

Penelitian secara empiris terkait dengan asimetri informasi pertama kali diperkenalkan oleh Akerlof pada tahun 1970. Temuan perdana tersebut memperlihatkan bahwa asimetri informasi menghalangi kemampuan investor untuk membedakan antara peluang ivestasi yang baik dan yang buruk, menciptakan biaya tambahan melalui promosi seleksi yang merugikan, dan menurunkan tingkat likuiditas (Vergauwe \& Gaeremynck, 2019). Dampak merugikan asimetri informasi tersebut menuntut perusahaan mencarikan formulasi untuk menekan asimetri informasi tersebut.

\section{Kualitas Pengungkapan}

Ada beberapa teori utama yang menjelaskan pentingnya pengungkapan perusahaan. Menurut Alwardat (2019) The Signaling Theory menunjukkan bahwa perusahaan dapat diklasifikasikan menurut dimensi seperti kualitas dan kinerja berdasarkan sejauh mana informasi keuangan dan non-keuangan yang mereka ungkapkan dalam laporan mereka. Tingkat pengungkapan perusahaan yang tinggi mengurangi asimetri informasi antara perusahaan dan saat ini maupun prospektif investor, yang cenderung meningkatkan persepsi investor tentang kualitas laporan keuangan perusahaan ini. Dalam hal keputusan kebijakan akuntansi yang harus diadopsi oleh perusahaan. Signaling Theory memprediksi perusahaan dengan laporan berkualitas tinggi lebih cenderung memilih kebijakan akuntansi yang memungkinkan kualitas superiornya diungkapkan. Perusahaan-perusahaan ini, bersedia mendapatkan keuntungan dari komunikasi terbuka dengan investor untuk menunjukkan keunggulan kompetitif mereka. Sementara itu, perusahaan dengan kualitas laporan yang lebih rendah akan berusaha untuk menyembunyikan laporan tersebut dan oleh karena itu akan membuat tingkat pengungkapan perusahaan yang rendah (Alwardat, 2019).

\section{Struktur Kepemilikan}

Salah satu ciri dari emiten modern adalah struktur kepemilikan yang tersebar luas. Kepemilikan saham berbagai pemegang saham menimbulkan benturan kepentingan antar pemegang saham, sehingga mempengaruhi kinerja perusahaan. Dengan demikian, struktur kepemilikan yang tepat dapat mendukung perusahaan untuk memiliki kinerja yang baik di pasar. Misalnya, meskipun kepemilikan yang terkonsentrasi oleh pemilik institusional dapat membawa efek positif pada kinerja perusahaan, tingkat konsentrasi kepemilikan yang tidak tepat dapat membawa efek negatif pada kinerja perusahaan (Zhang \& Kyaw, 2016)

Dewan direksi menjalankan dua fungsi penting seperti memantau tindakan manajemen dan alokasi sumber daya. Namun, peran Direksi sangat bergantung pada struktur kepemilikan, misalnya, peran pemantauan lebih penting dalam organisasi di mana pemegang saham tersebar sedangkan peran menyediakan sumber daya sangat penting bagi Direksi di mana kepemilikan terkonsentrasi mendominasi. Masalah keagenan (Konflik kepentingan antara prinsip dan agen) sangat bergantung pada struktur kepemilikan, pemilik yang tersebar dengan sedikit kepentingan dalam organisasi tidak repot-repot memantau tindakan manajer secara ketat. Di sisi lain, investor besar yang memiliki saham lebih besar dalam organisasi lebih tertarik untuk memantau manajemen melalui representasi di dewan, tetapi muncul masalah keagenan lain antara pemegang saham besar dan minoritas (Ahmad Abu Zraiq, 2018).

Hipotesis dalam penelitian ini adalah

\section{Kualitas Pengungkapan dan asimetri informasi}

Pengungkapan akuntansi merupakan salah satu mekanisme yang baik untuk memobilisasi informasi dari pihak manajemen dan investor sehingga dapat mengurangi asimetri informasi. Informasi akuntansi termasuk pengungkapan akuntansi memainkan peran penting dalam pasar modal yang berkembang dengan baik. Pertama, informasi akuntansi memungkinkan mereka yang menyediakan modal perusahaan termasuk pemegang saham dan kreditor untuk mengevaluasi potensi pengembalian peluang investasi menilai atau peran ex-ante informasi akuntansi. Kedua, informasi akuntansi memungkinkan mereka yang menyediakan modal perusahaan untuk memantau penggunaan modal yang dikontribusikan kepada perusahaan peran penata layanan atau ex-post informasi akuntansi. Umumnya, masalah keagenan dan asimetri informasi membatasi alokasi optimal sumber daya di pasar modal (Shiri et al., 2016).

Perbaikan kualitas pengungkapan memiliki peran penting dalam mengurangi asimetri informasi. Kualitas pengungkapan yang lebih baik akan meningkatkan visibilitas perusahaan dan mengurangi 
biaya pemrosesan informasi publik dan mendorong peningkatan penjualan saham perusahaan oleh investor yang tidak terinformasi. Terdapat dua jalan kualitas pengungkapan mempengaruhi asimetri informasi yaitu pertama dengan mengubah perilaku perdagangan investor yang kurang informasi dan kedua mengubah insentif untuk mencari informasi (Brown \& Hillegeist (2007). Teori tersebut idukung oleh banyak penelitian sebelumnya diantaranya Shiri et al (2016), Michaels \& Grüning (2017), Rodrigues \& Galdi (2017), Nel et al (2018), Vergauwe \& Gaeremynck (2019), ,Almurni \& Hendrawati (2019), dan Al-Sakini (2019) menemukan bahwa kualitas pengungkapan berpengaruh negatif terhadap asimetri informasi.

H1: Kualitas Pengungkapan berpengaruh negatif terhadap asimetri informasi

\section{Struktur Kepemilikan dan asimetri informasi}

Berdasarkan hipotesis pemantauan aktif, keberadaan investor utama diantara pemegang saham perusahaan atau kepemilikan terkonsentrasi dapat mengurangi asimetri informasi dan pada giliranya mengurangi biaya agensi, terutama karena peran pemantauan perusahaan (Shiri et al, 2016). Akan tetapi, berdasarkan hipotesis kepentingan pribadi, investor institusi memeiliki lebih banyak insentif untuk mengakses informasi pribadi tentang perusahaan untuk tujuan perdagangan mereka. Dalam situasi ini, investor ini kurang tertarik untuk memantau aktivitas perusahaan dan lebih tertarik pada pengungkapan oleh perusahaan dan, oleh karena itu, cenderung meningkatkan asimetri informasi dikarenakan peningkatkan masalah keagenan (Shiri et al., 2016).

Penelitian Boubaker et al (2015) terkait faktorfaktor tata kelola perusahaan, khususnya karakteristik dewan direksi dan kepemilikan manajerial dan pengungkapan sukarela dalam meningkatkan lingkungan informasi perusahaan non perbankan. Hasil temuanya menunjukan bahwa praktik tata kelola perusahaan tersebut tampaknya berfungsi sebagai pemantauan yang efektif bagi para eksekutif puncak perusahaan dan mengurangi asimetri informasi antara orang dalam dan orang luar. Penelitian Shiri et al (2016) yang menemukan bahwa struktur kepemilikan yaitu konsentrasi kepemilikan saham atau kepemilikan utama memiliki pengaruh positif terhadap asimetri informasi dikarenakan meningkatnya masalah keagenan yang ditimbulkan.

$\mathrm{H} 2$ : Konsentrasi kepemilikan berpengaruh negatif terhadap asimetri informasi

H3: Kepemilikan institusional berpengaruh positif terhadap asimetri informasi

\section{METODE PENELITIAN}

\section{Populasi dan sampel}

Penelitian ini menggunakan populasi seluruh perusahaan yang terdaftar di Jakarta Islamic Index
(JII) sebagai populasi objek penelitian. Pemilihan sampel dalam penelitian ini menggunakan metode purposive sampling, dimana peleiti menyeleksi perusahaan yang tetap konsisten berada di bursa selama lima tahun berturut mulai dari 20015-2019. Setelah penyeleksian data, penelitian menetapkan perusahaan pada bursa saham syariah yang terdaftar di JII sebagai sampel penelitian.Pemeilihan sampel penelitian tersebut bertujuan untuk kemudahan penelitian, karena perusahaan yang terdaftar JII memiliki kewajiban untuk mempublikasi laporan keuangan tahunan mereka. Data diambil dari website resmi JII dan wesite masing-masing perusahaan selama periode 2015-2019.

\section{Definisi Operasional dan Pengukuran Variabel \\ a. Asimetri Informmasi}

Adapun proksi yang kami gunakan dalam pengukuran asimetri informasi adalah bid-ask spread dimana spread dinyatakan dalam dalam poin, yaitu satuan terkecil dari sebuah pergerakan harga (Shiri et al., 2016)). Model perhitungan yang dipakai sebagai berikut:

$$
\text { SPREAD }=\frac{\left(a s k_{i, t}-b i d_{i, t}\right)}{\left\{\left(a s k_{i, t}+b_{i, t}\right) / 2\right\}} \times 100
$$

Keterangan:

Ask $_{\mathrm{i}, \mathrm{t}}$ : Harga permintaan tertinggi saham perusahaan I yang terjadi pada hari $\mathrm{t}$

Bid $_{i, t} \quad$ : Harga penawaran terendah perusaan I yang terjadi pada hari $\mathrm{t}$

\section{b. Kualitas pengungkapan keuangan}

Penelitian ini menggunakan relevansi nilai sebagai proksi dari kualitas pelaporan keuangan. Melalui perspektif Belief adjustment theory atau teori penyesuaian kepercayaan, penggunaan model return sebagai proksi dinilai lebih relevan dikarenakan model ini dapat mengukur prior belief dan current belief para investor dalam melakukan keputusan dalam investasi beli, jual atau menahan suatu sekuritas (Kusuma \& Agusti, 2014.). Untuk mengukur variabel relevansi nilai digunakan skema order nilai negatif dari adjusted $R^{2}$. Adapun rumus yang digunakan dalam menghitung relevansi nilai adalah sebagai berikut:

Value relevance $=-\mathrm{R}^{2}{ }_{\mathrm{jt}}$

Skema nilai negative dari adjusted $\mathrm{R}^{2}$ diperoleh dari persamaan berikut:

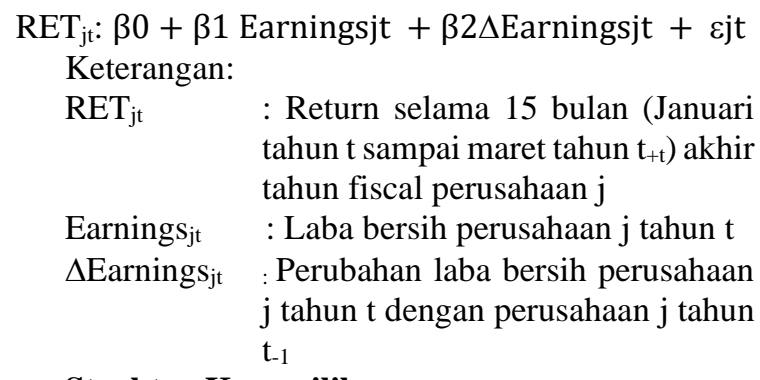

\section{c. Struktur Kepemilikan}


Penelitian ini menggunakan dua proksi untuk mewakili struktur kepemilikan seperti yang disarankan oleh Shiri et al (2016) yaitu konsentrasi kepemilikan dan kepemilikan institusional. Konsentrasi kepemilikan adalah persentase saham yang dimiliki oleh pemilik utama. Pemegang saham yang memiliki lebih dari 5 persen dari seluruh saham yang beredar pada akhir tahun diklasifikasikan sebagai pemilik utama.Sementara Kepemilikan intitusional yang dimaksud adalah persentase saham yang dimiliki pemerintah dan perusahaan publik lainya.

\section{Metode Analisis}

Peenelitian ini menggunakan metode deskriptif kuantitatif dengan menggunakan alat analisis data panel. Data panel merupakan data yang diperoleh dari data cross section yang diobservasi secara berulang pada unit individu (objek) yang sama pada waktu yang berbeda. Model ini punya kelebihan dapat mengontrol unobserved heterogeneity, lebih informatif, mempelajari model prilaku yang lebih kompleks, mengurangi kolenieritas, memperbesar derajat kebebasan dan efisien serta dapat mengukur efek suatu variabel pada variabel lainya dengan lebih baik dibandingkan hanya menggunakan data time series atau cross section sehigga dapat mengurangi bias dalam penarikan simpulan (Juanda \& Junaidi, 2012).

Model kualitas pengungkapan ke asimetri informasi:

$$
\begin{gathered}
Y=\beta_{0 i}+\beta_{1} \text { Kualitas }_{i t}+\beta_{2} \text { Konsentrasi }_{2 t} \\
+\beta_{3} \text { Institusi }_{3 t}+\varepsilon_{i t}
\end{gathered}
$$

Dimana :

$$
\begin{array}{ll}
\text { Y } & : \text { Asimetri Informasi } \\
\text { Kualitas } & : \text { Kualitas Pelaporan Keuangan } \\
\text { Konsentrasi } & : \text { Konsentrasi Kepemilikandiatas } \\
& 5 \% \\
\text { Institusional } & : \text { Kepemilikan Institusional }
\end{array}
$$

\section{HASIL DAN PEMBAHASAN}

\section{Hasil Regres}

Setelah melakukan uji data panel menggunakan prangkat eviews, penelitian ini menggunakan metode analisis regresi Pool Ordinary Least Square (PLS), dan dari hasil pemilihan model terbaik yang

\begin{tabular}{|c|c|c|c|c|}
\hline Institusional & $\begin{array}{l}1.60996 \\
1\end{array}$ & $\begin{array}{l}2.37022 \\
9\end{array}$ & $\begin{array}{l}0.023 \\
3\end{array}$ & $\begin{array}{l}\text { Signifik } \\
\text { an }\end{array}$ \\
\hline $\begin{array}{l}\text { Adj.R- } \\
\text { Squared }\end{array}$ & $\begin{array}{l}0.42642 \\
7\end{array}$ & & \multirow{3}{*}{\multicolumn{2}{|c|}{$\alpha 0,05$}} \\
\hline F-Statistik & 3.527752 & & & \\
\hline $\begin{array}{l}\text { Prob(F- } \\
\text { Statistik) }\end{array}$ & 0.000969 & & & \\
\hline
\end{tabular}
ditemukan dalam pemilihan model ini adalah model Fix Effect Model (FEM). Adapun hasil dari olah data eviews sebagai berikut:

Tabel 1: Hasil Olah Data Panel Model Fix Effect Model (FEM)

\begin{tabular}{|l|l|l|l|l|}
\hline Variabel & $\begin{array}{l}\text { Koefisie } \\
\mathrm{n}\end{array}$ & $\begin{array}{l}\text { t- } \\
\text { Statistik }\end{array}$ & $\begin{array}{l}\text { Proba } \\
\text { bilitas }\end{array}$ & $\begin{array}{l}\text { Kesimp } \\
\text { ulan }\end{array}$ \\
\hline Kualitas & - & - & 0.176 & Tidak \\
& $\begin{array}{l}29.7933 \\
8\end{array}$ & $\begin{array}{l}1.37841 \\
6\end{array}$ & $\begin{array}{l}\text { Signifik } \\
\text { an }\end{array}$ \\
\hline Konsentrasi & 3.97278 & 0.14175 & 0.888 & $\begin{array}{l}\text { Tidak } \\
\text { Signifik } \\
\text { an }\end{array}$ \\
\hline & 1 & 7 & 1 & \\
\hline
\end{tabular}

\section{Sumber: Data Diolah}

Berdasarkan tabel hasil olah data panel diatas yang menunjukan antara variabel kualitas pengungkapan dan struktur kepemilikan perusahaan terhadap asimetri asimetri informasi, secara keseluruhan baik kualitas pengungkapan dan struktur kepemilikan memiliki pengaruh terhadap asimetri informasi. Hal tersebut dapat dilihat dari hasil uji simultan (Uji F) F hitung sebesar 3.527752 yang melebih F-tabel dengan probabilitas 0.000969 yang kurang dari $\alpha 0,05$ maka dapat disimpulkan secara simultan semua variabel memiliki pengaruh terhadap asimetri informasi. Selain itu jika dilihat dari nilai koefisiennya atau berdasarkan uji determinasi nilai Adj.R-Square sebesar 0,426427 atau dapat kita simpulkan semua variabel bebas dapat dijelaskan variabel asimetri informasi sebesar $42 \%$ sementara sisanya dijelaskan oleh variabel lain diluar penelitian ini.

Sedangkan berdasarkan uji signifikansi individu (Uji T), dari ketiga variabel yang di uji secara parsial, hanya variabel kepemilikan institusional yang memiliki pengaruh terhadap asimetri informasi sedangkan variabel kualitas pengungkapan dengan proksi relevansi nilai kualitas pengungkapan dan konsentrasi kepemilikan diatas 5\% yang mewakili dari struktur kepemikan tidak memiliki pengaruh secara statistik terhadap asimetri informasi. Berdasarkan tabel diatas kepemilikan institusional berpengaruh positif signifikan terhadap asimetri informasi. Hal tersebut dapat dilihat dari nilai koefisiensi sebesar 1.609961dengan nilai probailitas t-statistik 0,0233 atau kurang dari $\alpha$ 0,05 dengan demikian dapat disimpulkan kepemilikan institusional berpengaruh positif terhadap asimetri informasi.

\section{Pembahasan}

\section{a. Pengaruh Kualitas Pengungkapan terhadap asimetri informasi}

Hasil penelitian ini membuktikan bahwa kualitas pengungkapan yang diproksikan oleh relevansi nilai tidak berpengaruh terhadap asimetri informasi pada perusahaan yang terdaftar di bursa saham Jakarta Islamic Index (JII) selama 2015-2019. Hal tersebutmempertegas bahwa asimetri informasi tidak dipengaruhi atau dikurangi oleh kualitas pengunkapan seperti dugaan atau hipotesis dalam penelitian ini. Dengan kata lain, upaya dari manajer perusahaan dalam menyajikan laporan keuangan berkualitas dan memiliki nilai relevansi nilai bagi pasar saham tidak belum dapat memberikan pandangan kepada investor sehingga beberpa 
investor tidak bereaksi positif atas hal tersebut dengan demikian asimetri informasi tidak dapat terhindarkan.hasil penelitian ini sejalan dengan penelitian Kusuma dkk (2015) yang menemukan bahwa kualitas pengungkapan tidak berpengaruh terhadap asimetri informasi pada 14 perusahaan yang terdaftar di Bursa efek Indonesia. Hasil ini bertentangan dengan penelitian Shiri dkk (2016) yang menemukan bahwa kualitas pengungkapan berpengaruh negatif signinifikan terhadap asimetri informasi.

\section{b. Pengaruh Konsentarsi Kepemilikan terhadap Asimetri Informasi}

Hasil penelitian ini menunjukan bahwa konsentrasi kepemilikan tidak memiliki pengaruh terhadap asimetri informasi perusahaan yang terdaftar di Jakarta Islamic Index (JII) selama 20152019. Hal tersebut menjelaskan bahwa keberadaan investor utama diantara pemegang saham perusahaan tidak dapat mengurangi asimetri informasi ditengah investor. Berdasarkan hipotesis pemantauan aktif, keberadaan investor utama di antara pemegang saham perusahaan seharusnya dapat mengurangi asietri informasi ditengah investor dan pada giliranya mengurangi biaya agensi, terutama karnea peran pemantauan investor tersebut. Hasil penelitian ini bertentangan dengan penelitian sebelumnya yang dilakukan oleh Shiri dkk (2016) yang menemukan bahwa konsentrasi kepemilikan berpengaruh positif terhadap asimetri informasi.

\section{c. Pengaruh Kepemilikan Institusional terhadap asimetri informasi}

Hasil penelitian ini menemukan bahwa kepemilikan institusional berpengaruh positif terhadap asimetri informasi. Dengan demikian temuan ini sejalan berdasarkan hipotesis kepentingan pribadi, investor institusional dan investor besar memiliki lebih banyak insentif untuk mengakses informasi pribadi tentang perusahaan untuk tujuan perdagangan mereka. selain itu, dalam kondisi tersebut investor besar kurang tertarik untuk memantau aktivitas perusahaan dan lebih tertarik pada pengungkapan oleh perusahaan sehingga pada giliranyameningkatkan masalah agensi atau konflik kepentingan.konflik kepentingan tersebut menimbulkan biaya yang dikarenakan adanya asimetri informasi.Atau dengan kata lain, ketika struktur kepemilikan tersebut tersebar pada investor institusional atau pihak luar makan rentan terjadi konflik kepentingan karena benturan kepentingan antar pihan investor luar dengan pihak direksi yang jga memiliki saham pada perusahaan tersebut (Kusuma, 2015). Hasil tersebut sejalan dengan penelitian sebelumnya yang dilakukan oleh Shiri dkk (2016) yang menemukan bahwa kepemilikan institusional berpengaruh positif terhadap asimetri informasi.

\section{KESIMPULAN}

Kualitas pengungkapan dan struktur kepemilikan punya peranan penting dalam asimetri informasi. Setelah melakukan pengujian analisis data panel dan menemukan model Fixed Effect Model (FEM) sebagai model terbaik, hasil penelitan ini menunjukan bahwa secara simultan ketiga variabel yang mewakili kualitas pengungkapan dan struktur kepemilkan memliki pengaruh terhadap asimetri informasi. Sedangkan secara parsial, hanya keemilikan institusional yang memiliki pengaruh positif signifikan terhadap asimetri informasi sedangkan, relevansi nilai proksi dari kualitas pengungkapan dan konsentasi kepemilikan tidak berpengaruh terhadap asimetri informasi pada investor perusahaan yang terdaftar di Jakarta Islamic Index (JII) selama periode 2015-2019. Penelitian ini masih terbatas pada satu proksi dari kualitas pengungkapan yakni relevansi nilai laporan keuangan. Saran untuk penelitian selanjutnya mengembangkan proksi lain dari kualitas pengungkapan seperti nilai Internet Investor Relatioan (IIR), Timelines, dan Conservatisme.Selain itu, juga perlu menggunakan variabel determinan lain seperti tata kelola dan pengungkapan sukarela dalam mengukur asimetri informasi.

\section{REFERENSI}

Ahmad Abu Zraiq, M. (2018). The Impact of Ownership Structure on Firm Performance: Evidence from Jordan. International Journal of Accounting, Finance and Risk Management, $3(1), \quad 1$. https://doi.org/10.11648/j.ijafrm.20180301.12

Almurni, S., \& Hendrawati, -. (2019). Effect of Quality of Financial Reporting to Asymmetry Information on Manufacturing Company in BEI. Proceedings of the 5th Annual International Conference on Accounting Research (AICAR 2018). Proceedings of the 5th Annual International Conference on Accounting Research (AICAR 2018), Manado, Indonesia. https://doi.org/10.2991/aicar-18.2019.21

Al-Sakini, S. (2019). The Impact Of Disclosure Of The Financial Statements At The Level Of Information Asymmetry Between Investors: An Empirical Study On The Commercial Banks In Jordan. 23(5), 17.

Alwardat, Y. (2019). Disclosure Quality and its Impact on Financial Reporting Quality, Audit Quality, and Investors' Perceptions of the Quality of Financial Reporting: A Literature Review. Accounting and Finance Research, 8(3),201https://doi.org/10.5430/afr.v8n3 p201

Bergh, D. D., Ketchen, D. J., Orlandi, I., Heugens, P. P. M. A. R., \& Boyd, B. K. (2019). Information Asymmetry in Management 
Research: Past Accomplishments and Future Opportunities. Journal of Management, 45(1), 122-158. https://doi.org/10.1177/0149206318798026

Boubaker, S., Hamrouni, A., \& Liang, Q.-B. (2014). Corporate Governance, Voluntary Disclosure, And Firm Information Environment. Journal of Applied Business Research (JABR), 31(1), 89. https://doi.org/10.19030/jabr.v31i1.8993

Cheynel, E., \& Levine, C. (2019). Public Disclosures and Information Asymmetry: A Theory of the Mosaic. The Accounting Review, 47.

Kusuma, T., \& Agusti, R. (2014). Pengaruh Kualitas Pelaporan Keuangan, Kepemilikan Institusional Dan Ukuran Perusahaan Terhadap Asimetri Informasi Pada Perusahaan Perbankan Yang Terdaftar Di Bei Tahun 2008-2012. 15.

Michaels, A., \& Grüning, M. (2017). Relationship of corporate social responsibility disclosure on information asymmetry and the cost of capital. Journal of Management Control, 28(3), 251274. https://doi.org/10.1007/s00187-0170251-z

Nel, G. F., Smit, E., \& Brummer, L. M. (2018). The link between Internet investor relations and information asymmetry. South African Journal of Economic and Management Sciences, 21(1). https://doi.org/10.4102/sajems.v21i1.1966

Rodrigues, S. da S., \& Galdi, F. C. (2017). Investor relations and information asymmetry. Revista Contabilidade \& Finanças, 28(74), 297-312. https://doi.org/10.1590/1808-057x201703630

Shiri, M. M., Salehi, M., \& Radbon, A. (2016). A Study of Impact of Ownership Structure and Disclosure Quality on Information Asymmetry in Iran. Vikalpa: The Journal for Decision Makers, 41(1), 51-60. https://doi.org/10.1177/0256090915620876

Vergauwe, S., \& Gaeremynck, A. (2019). Do measurement-related fair value disclosures affect information asymmetry? Accounting and Business Research, 49(1), 68-94. https://doi.org/10.1080/00014788.2018.1434 608

Zhang, H., \& Kyaw, K. (2016). Ownership Structure and Firm Performance: An Empirical Analysis of Chinese Companies. Applied Economics and Finance, 4(2), 57. https://doi.org/10.11114/aef.v4i2.2109 